
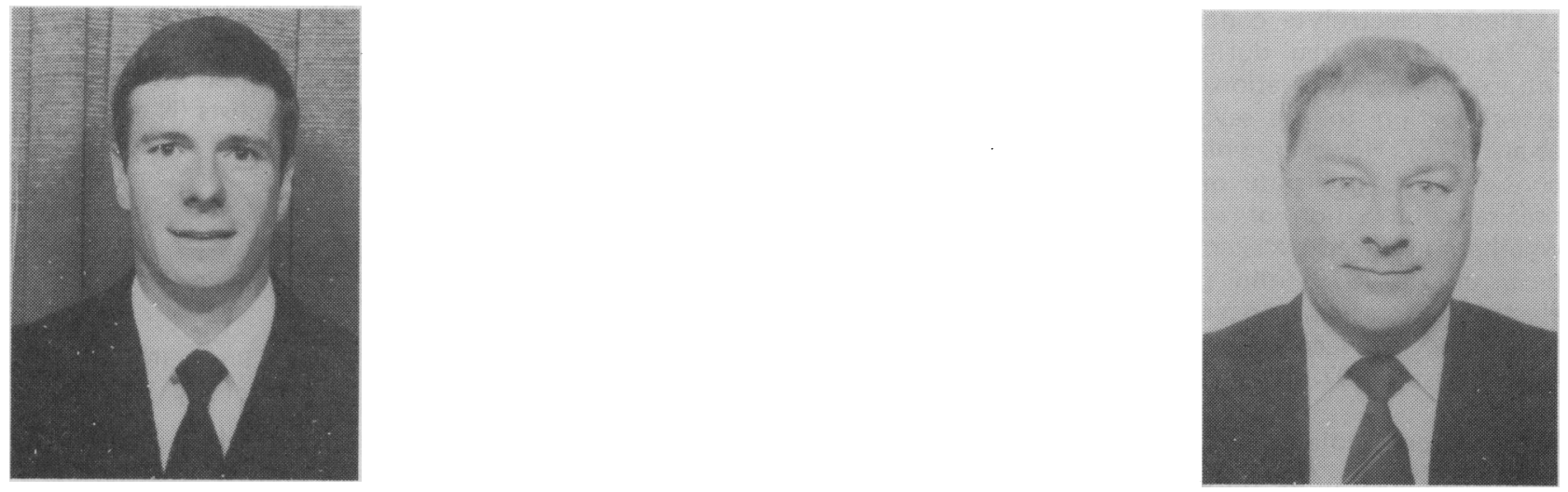

\title{
THE HYDRATION AND ELECTROLYTE MAINTENANCE PROPERTIES OF AN EXPERIMENTAL SPORTS DRINK
}

\author{
J. WHITE, PhD* and M. A. FORD, ARIC, AIFST \\ *Human Performance Laboratory, Department of Human Kinetics, Salford University, \\ Salford M5 4WT, Lancashire \\ tBeecham Products, Research and Development Division, The Royal Forest Factory, \\ Coleford, Gloucester GL16 8JB
}

\begin{abstract}
Seven highly trained subjects underwent exercise dehydration without fluid replacement $(X)$, resulting in $\sim 1.9 \%$ and $\sim 3.5 \%$ body weight (fluid) losses at one and two hours, respectively. Subsequently, subjects underwent two identical exercise trials with isovolumetric fluid replacement of water (W) and an experimental formulation (Q). An antidehydration schedule was initiated prior to, and continued throughout the exercise, with $W$ and $Q$ supplied every 15 minutes at $16^{\circ} \mathrm{C}$ in volumes related to each subject's fluid loss estimate derived from trial $X$. A rehydration schedule was maintained for two hours of recovery, with total fluid replacement equivalent to the body weight decrement due to fluid losses.

In both $\mathrm{W}$ and $\mathrm{Q}$ trials, selected physiological indices of work performance were maintained closer to homeostatic levels during exercise, with a more rapid return to pre-exercise resting levels during recovery than during trial $X$. Furthermore, $\mathrm{W}$ and $\mathrm{Q}$ were equally effective in preventing plasma volume changes during exercise and restoration to pre-exercise levels during recovery, as well as in preventing plasma osmolality disturbances during exercise and recovery, although minimal plasma electrolyte changes were associated with $Q$.
\end{abstract}

Key Words: Exercise dehydration, Fluids, Electrolytes, Cyclists.

\section{INTRODUCTION}

\section{Dehydration Studies}

Dehydration produced by diuresis induces physiological intolerance to heat and exercise, resulting from a reduction in plasma volume (Claremont et al, 1976). Likewise, exercise and thermal dehydration induce similar reductions in plasma volume (Costill and Fink, 1974) as well as increased plasma osmolality (Costill et al, 1974) and the magnitude of plasma volume and plasma osmolality changes is related to exercise intensity and duration (Costill and Fink, 1974).

Total body fluid losses during exercise in the heat result from relative shifts in the distribution of fluids from both the intra-cellular and extra-cellular compartments (Costill, Cote and Fink, 1976). Moreover, plasma water and muscle water decreases during exercise and thermal dehydration are related to percentage decreases in body weight (Costill et al, 1976). 
Plasma electrolyte concentrations remain unchanged or become elevated during dehydration states, while intracellular concentration of some electrolytes increase in proportion to the severity of dehydration (Costill et al, 1976). However, while human perspiration may be considered as a filtrate of plasma (Costill, 1979) the precise composition of which may vary according to whether produced by exercise or thermal factors (Pilardeau et al, 1979) the physiological significance of electrolyte losses in perspiration during exercise may be considered of secondary importance to body water losses (Costill, 1979).

\section{Rehydration Studies}

Fluid administration during exercise can prevent or offset plasma volume changes and maintain body temperature closer to resting or homeostatic levels (Costill, Kammer and Fisher, 1970). Furthermore, rapid fluid replacement following thermal dehydration, has a favourable effect on cardiovascular response to exercise, but it may not restore plasma volume or serum osmolality to pre-dehydration values (Costill and Sparks, 1973).

Rehydration with water or glucose-mineral solutions may prevent the increase in sodium and chloride concentrations in plasma during exercise (Costill et al, 1970) and minimise the decline of these electrolytes during recovery from prolonged exercise (Costill and Sparks, 1973). Furthermore, the rehydration properties of fluids, in terms of maximisation of gastric emptying, appear to be enhanced if the solutions used are relatively dilute (Costill and Saltin, 1974; Foster, Costill and Fink, 1980). However, the addition of electrolytes to fluids following repeated dehydration on successive days appears to have minimal value when ad libitum access to food and drink is available (Costill et al, 1975).

\section{METHODS}

\section{Field Trial}

Prior to undertaking the laboratory trials, a field trial study was conducted, in order to provide information concerning the relative fluid demands placed upon racing cyclists during actual event conditions. The findings of a medium-distance cycle road race are presented in Table 1.

The environmental conditions under which the race took place may be considered "ideal" for a cycle road race, in that temperature, humidity and windspeed were not likely to have adversely affected performance. The event, which took place on an undulating, enclosed circuit, attracted top category riders and was completed at an average speed of $\sim 42 \mathrm{kmh}^{-1}$ and, thus, could be considered as representative of the standards achieved by elite cycling endurance performers in the United Kingdom.

\section{TABLE I}

The effects of road cycle racing upon body weight (fluid) losses in competitive cyclists $(\mathbf{N}=7)$

Distance: $103 \mathrm{~km}$

Time: 2 hr. $27 \mathrm{~min} .34 \mathrm{sec}$

Average speed: $41.9 \mathrm{kmh}$

\section{ENVIRONMENTAL CONDITIONS}

Temperature

Relative Humidity

Wind

Atmospheric Pressure

Pre-race Weight (kg)

Post-race Weight (kg)

Fluid Ingested (mI)

Body Weight Loss (kg)

Body Weight Loss (\%)

The findings of the field trial may be summarised as follows:-

(i) Body weight losses incurred averaged $3.25 \%$ in the group selected for study $(\mathrm{N}=7)$.

(ii) Relatively low volumes of fluid were ingested during the race, even though fluid was freely available.

Additionally, further observations upon the group revealed:

(iii) A disparity between individual competitor's pre-race estimates of fluid intake and volumes actually ingested.

(iv) An absence of a relationship between fluid intake volume and finishing position.

(v) Little or no fluid intake in two competitors who retired early with symptoms of heat distress.

It was concluded from the findings that relatively large body weight (fluid) losses may be incurred as a result of competition, even during environmental conditions which are not oppressive. Indeed, fluid losses appeared to be in the order of experimentally produced conditions which have been shown to impair thermoregulatory function, as well as cardiorespiratory performance (see review of literature).

\section{Subjects}

The general characteristics of the seven subjects, who underwent the dehydration/rehydration trial tests, are presented in Table II. The data, which were collected using standardised human performance laboratory techniques, are typical of elite highly-trained endurance performance athletes who characteristically show low body fat content, enhanced lung function, a normal haematological profile and an enhanced capacity for 
TABLE II

General characteristics of the experimental subjects in the study $(N=7)$

\section{ANTHROPOMETRY}

Age (yrs)

Height $(\mathrm{cm})$

Weight (kg)

Skinfold Thickness $(\mathrm{mm})$

\% Body Fat (Estimated)

\section{LUNG FUNCTION}

Forced Vital Capacity (L)

Forced Expired Volume ${ }_{1}$ sec (L)

Forced Expired Volume (\%)

\section{HAEMATOLOGY}

Haemoglobin (g./d.cl.)

Packed Cell Volume (\%)

MAXIMAL EXERCISE RESPONSES

Heart Rate (b. $\mathrm{min}^{-1}$ )

Ventilation Volume (I. $\left.\mathrm{min}^{-1}\right)$

Oxygen Consumption (ml. kg. $\mathrm{min}^{-1}$ )

Respiratory Exchange Ratio

physical work performance, as demonstrated by physiological criteria. Maximal cardiorespiratory performance variables were established, utilising a recently-developed cycle ergometry system (Firth, 1981) and a graded exercise protocol based on each subject's variable gearing ratio, with a two minute incremental stepped increase in gear size at a constant pedal speed of $90 \mathrm{rpm}$ until standardised maximal respiratory $\left(\mathrm{VO}_{2} \max \right)$ criteria had been achieved (White et al, 1982).

\section{Experimental Protocol}

The experimental design utilised for the dehydration/ rehydration series of trials consisted of three separate phases:-

1. The preparatory phase consisted of standardised dietary and exercise habits of the subjects on the days prior to, and day of, each trial, as well as a 30 minutes rest period immediately before each test was conducted.

2. The experimental phase consisted of two hours of each treatment at an exercise level sustained at approximately $67 \%$ of each subject's previously established aerobic maximal level $\left(\mathbf{V O}_{2}\right.$ max). Cardiorespiratory variables were determined at $\mathbf{2 0}$ minute intervals to ensure the stability of physiological levels of work.

Venous blood samples were obtained initially, and, at one and two hours of exercise, for the assessment of haematological indices and plasma variables.

$\begin{array}{cc}x & \pm S . E . \\ 21.0 & 0.6 \\ 176.3 & 2.3 \\ 66.1 & 3.1 \\ 24.0 & 1.6 \\ 10.2 & 0.7 \\ & \\ & \\ 5.76 & 0.25 \\ 4.81 & 0.28 \\ 83.3 & 3.1 \\ & \\ & \\ 14.9 & 0.5 \\ 43.6 & 0.8 \\ & \\ 190.6 & 3.3 \\ 143.7 & 6.7 \\ 69.5 & 2.1 \\ 1.14 & 0.03\end{array}$

\begin{tabular}{rlr}
\multicolumn{3}{c}{ Range } \\
18.4 & -23.5 \\
170.2 & - & 184.1 \\
54.6 & - & 77.6 \\
21.0 & - & 32.9 \\
8.6 & - & 14.0
\end{tabular}

Likewise, body weight, core (rectal) temperature and fluid (weight) loss estimates were obtained on the sáme schedule. A five minute delay occurred between the first and second hour of the experiment, in order to allow each subject a change of clothing before continuing with the experiment.

3. The replacement phase consisted of a three hour recovery period when the subjects rested in a reclining position, with all relevant data collected at $1 / 2,1,2$ and 3 hours following the exercise.

\section{Treatments}

As a necessary pre-condition, treatment $X$ (no fluid) was applied initially in all subjects and specified as the dehydration trial. During this trial, an attempt was made to reduce each subject's body weight, via fluid losses, by $\sim 2 \%$ and $\sim 4 \%$, after one and two hours of exercise, respectively. The purpose of this approach was to determine each individual's fluid loss capability, in order to devise a suitable fluid replacement schedule for the subsequent $W$ and $Q$ treatments, and to establish the level of work load required to establish fluid losses in the order of $\sim 2 \%$ and $\sim 4 \%$ of each subject's body weight, in order that such work loads could be replicated in the anti-dehydration schedules developed for the W (water) and $Q$ (experimental fluid) treatments.

Treatments $\mathrm{W}$ and $\mathrm{Q}$ were applied at 15 minute intervals, beginning 30 minutes prior to the onset of the experiment, throughout the duration of the exercise, and for two hours of the total three hour recovery 
period. The total volume supplied was equivalent to each subject's fluid (weight) loss estimate obtained from the dehydration trial $X(2.30 \mathrm{~kg} \pm 0.51 ; 2,300 \mathrm{ml} \pm 81)$, in 18 equal volumes served from previously prepared thermos flasks at a cold tap water temperature of $16^{\circ} \mathrm{C}$. Whereas treatment $X$ was applied initially, treatments $\mathrm{W}$ and $\mathrm{Q}$ were applied randomly to all subjects in an attempt to remove any order effects from the experimental results. The composition of the experimental drink is presented in Table III.

\section{TABLE III}

Electrolyte concentrations and energy content of the experimental drink (Q)

\section{ELECTROLYTE CONCENTRATION $(\mathrm{mg} / 100 \mathrm{ml})$}

\begin{tabular}{|c|c|c|}
\hline & $\underset{\text { (Undiluted) }}{\mathrm{Q}}$ & $\underset{(1: 4 \text { Dilution) }}{\mathrm{Q}}$ \\
\hline Sodium & 250 & 50 \\
\hline Potassium & 50 & 10 \\
\hline Calcium & 31 & 6.2 \\
\hline Magnesium* & 5 & 1.0 \\
\hline Chloride & 200 & 40 \\
\hline Phosphate & 125 & 25 \\
\hline \multicolumn{3}{|c|}{ ENERGY CONTENT $(\mathrm{kJ} / 100 \mathrm{ml})$} \\
\hline Carbohydrate & 376.7 & 75.3 \\
\hline
\end{tabular}

* Only constituent for which estimates of plasma values not available from subsequent biochemical analyses

Attempts were made to control and standardise both the timing and environmental conditions under which the dehydration/rehydration trial series were conducted. Each individual undertook each experimental treatment $X, W$ and $Q$ on the same day of the week and at the same time of day. Furthermore, environmental conditions were maintained as uniform as possible (temperature $21^{\circ} \mathrm{C} \pm 0.5^{\circ} \mathrm{C}$, relative humidity $65 \% \pm 1.5 \%)$, in order to minimise the effect on the experimental results. In the absence of evaporative cooling effects of cycling under laboratory conditions, during each experiment, subjects were exercised in racing attire consisting of racing shorts, socks and cycling shoes only, with supplemental cooling provided by an electric fan directed towards the head and upper body region. Nevertheless, subjects perspired freely in all trials.

\section{Ergometry}

The method selected for simulating the exercise demand of road race cycling utilised a recently-developed ergometry system (Firth, 1981) which incorporated each subject's own road racing cycle, fitted with a "Racermate" wind load simulator mounted upon a set of steel cycle training rollers which has been described elsewhere (White et al, 1982).
The work loads selected for the duration of each experiment consisted of moderate to high intensity exercise which demanded $\sim 67 \%$ of each subject's previously-determined maximum aerobic power $\left(\mathrm{VO}_{2}\right.$ max) established during the pre-trial tests. Standardised work loads based upon each subject's average power output established during the no treatment $(X)$ trial, were replicated during each of the two fluid treatment (W and Q) trials. The intensity of work selected was commensurate with levels utilised in other studies cited in the literature which have been demonstrated to elicit exercise dehydration levels in the order of $\sim 4 \%$ body weight loss over a two hour period in highly trained experimental subjects.

\section{Physiological Analyses}

Cardiovascular indices of work were established by determination of heart rate, systolic blood pressure and rate/pressure product. Heart rates (b. $\mathrm{min}^{-1}$ ) were measured by an automated bipolar cardiometer. Systolic blood pressure $(\mathrm{mmHg})$ was recorded by the standard auscultatory technique, using a stethoscope and manual sphygmomanometer. The rate/pressure index of work was established as the product of heart rate (b. $\mathrm{min}^{-1}$ ) and systolic blood pressure $(\mathrm{mmHg})$ and recorded in arbitrary rate/pressure units. Respiratory indices of work were recorded, utilising the exercise programme of the Beckman Metabolic Measurement Cart (MMC). Subjects, wearing a nose clip, breathed via a rubber mouthpiece, through a low resistance valve attached by flexible plastic piping to the Beckman MMC. Internal body (core) temperature was determined, using a clinical thermometer with a rectal probe inserted to a depth of $20 \mathrm{~mm}$, and values recorded to the nearest $.01^{\circ} \mathrm{C}$. All physiological parameters were recorded in duplicate and averaged for the purpose of establishing temporal accuracy.

\section{Plasma Analyses}

Venous blood samples were obtained from the antecubital vein, using a venepuncture technique, and specimens prepared for plasma volume, osmolality and electrolyte determinations. Haemoglobin and packed cell volume $(\%)$ were determined, using a cyanmethhaemoglobin method, and standard microhaematocrit method, respectively. Utilising the values obtained, an estimate of the change $(\Delta \%)$ in plasma volume during exercise was calculated, according to the precedure described by Dill and Costill (1974).

Specimens for plasma, electrolytes and osmolality analyses were prepared from $5 \mathrm{ml}$ clotted blood, which was centrifuged at 2,000 rpm for 10 minutes following collection and stored at $4^{\circ} \mathrm{C}$. Separate specimens were prepared for glucose analysis from $1 \mathrm{ml}$ of blood collected in fluoride-EDTA tubes and mixed gently with anticoagulant before centrifugation, separation and 
storage at $4^{\circ} \mathrm{C}$. All plasma analyses were conducted by the Department of Clinical Pathology of Hope Hospital, Salford, using a Technicon Sequential Multiple Analysis Computerised (SMAC) System, using standardised clinical techniques. Duplicate samples were analysed for accuracy and compared with reference ranges developed from quality control standards.

\section{Statistical Analysis}

Inferential statistics in the form of one-way analyses of variance with repeated measures were used to detect treatment effects associated with each trial, with differences due to treatment means evaluated using the Tukey Test procedure.

\section{RESULTS}

\section{Physiological Changes}

A statistical summary of the mean physiological changes, associated with the dehydration/rehydration trial series, is presented in Table IV.

The physiological demands of exercise in terms of body weight, body temperature, cardiovascular and respiratory responses favoured the fluid treatment conditions in $W$ and $Q$ in comparison with the no fluid treatment condition $X$. There were marked, and often statistically, significant effects, demonstrated by one (Q) or both (W and $\mathrm{Q}$ ) fluid treatments, during exercise and following, throughout the duration of the post-exercise recovery period. This indicated that both the magnitude of physiological disturbance during exercise was minimised, as well as the return to pre-exercise homeostatic levels enhanced, in the case of fluid treatments, with a tendency for treatment $\mathrm{Q}$ to demonstrate the most consistent beneficial effect.

\section{Plasma Changes}

A statistical summary of the mean plasma changes associated with the dehydration/rehydration trial series is presented during exercise in Table $\mathrm{V}(\mathrm{a})$ and during recovery in Table $\mathrm{V}(\mathrm{b})$.

Plasma variable changes observed in terms of the order of magnitude of disturbance from pre-exercise homeostatic resting levels favoured the fluid treatment conditions $W$ and $Q$ in comparison with the no fluid treatment condition $X$. There were marked, and often statistically significant effects, demonstrated by either (W or $\mathrm{Q}$ ) or both (W and $\mathrm{Q}$ ) fluid treatments during exercise, and following throughout the recovery period, which indicated that both the magnitude of electrolyte disturbance (sodium, chloride and calcium) during exercise was minimised, as well as the return to pre-exercise homeostatic levels enhanced during recovery. Similarly, plasma volume and plasma osmolality changes were significantly influenced by treatment $Q$ and treatments $W$ and $Q$, respectively, during recovery, which indicated a more rapid restoration of plasma volume and plasma osmolality during the rehydration treatments.

Finally, treatment $\mathrm{Q}$ produced evidence of a carbo-

TABLE IV: MEAN PHYSIOLOGICAL CHANGES DURING EXERCISE AND RECOVERY

\begin{tabular}{|c|c|c|c|c|c|c|c|c|c|c|c|c|c|c|c|c|}
\hline \multirow{2}{*}{\multicolumn{2}{|c|}{$\begin{array}{l}\text { EXPERIMENTAL PHUSES } \\
\text { TIME (MIRUTES) }\end{array}$}} & \multirow{2}{*}{\multicolumn{3}{|c|}{$\frac{\text { REST }}{30 \text { (Pre-Exersise) }}$}} & \multicolumn{6}{|c|}{ EXERC ISE } & \multicolumn{6}{|c|}{ RECOVERY } \\
\hline & & & & & \multicolumn{3}{|c|}{60} & \multicolumn{3}{|c|}{120} & \multicolumn{3}{|c|}{150} & \multicolumn{3}{|c|}{300} \\
\hline TREATMENTS & & $x$ & $w$ & $Q$ & $x$ & W & $Q$ & $x$ & $w$ & $Q$ & $\mathbf{x}$ & $\mathbf{W}$ & $\mathbf{Q}$ & $x$ & $w$ & $Q$ \\
\hline BODY WT. (kg) & $\begin{array}{c}\bar{x} \\
\text { S.E. }\end{array}$ & $\begin{array}{r}66.2 \\
\pm \quad 3.0\end{array}$ & $\begin{array}{r}66.9 \\
\pm 3.1\end{array}$ & $\begin{array}{r}70.0 \\
\pm 3.1\end{array}$ & $\frac{64.9^{* 6}}{ \pm 3.0}$ & $\begin{array}{r}66.5 \\
\pm \quad 3.1\end{array}$ & $\begin{array}{r}66.6 \\
\pm \quad 3.1\end{array}$ & $\frac{63.8^{14}}{ \pm 2.9}$ & $\begin{array}{r}65.9 \\
\pm 3.1\end{array}$ & $\begin{array}{r}66.2 \\
\pm \quad 3.0\end{array}$ & $\frac{63.8^{* 17}}{ \pm 2.9}$ & $\begin{array}{r}66.2 \\
\pm \quad 3.1\end{array}$ & $\begin{array}{r}66.3 \\
\pm 3.1\end{array}$ & $\frac{63.7^{* * 1}}{ \pm 2.9}$ & $\begin{array}{r}66.7 \\
\pm \quad 3.1\end{array}$ & $\begin{array}{r}66.9 \\
-2.8\end{array}$ \\
\hline $\begin{array}{l}\text { RECTAL TEMP. } \\
\left({ }^{\circ} \mathrm{C}\right)\end{array}$ & $\begin{array}{c}\bar{x} \\
\text { S.E. }\end{array}$ & $\begin{array}{r}37.2 \\
\pm 0.1\end{array}$ & $\begin{array}{r}37.2 \\
\pm 0.2\end{array}$ & $\begin{array}{r}37.1 \\
\pm 0.2\end{array}$ & $\begin{array}{r}38.5 \\
\pm 0.2\end{array}$ & $\begin{array}{r}38.2 \\
\pm 0.2\end{array}$ & $\frac{38.0}{ \pm 0.3}$ & $\begin{array}{r}38.8 \\
\pm 0.3\end{array}$ & \begin{tabular}{|l}
$38.1^{\circ}$ \\
0.2
\end{tabular} & $\frac{38.27}{ \pm 0.2}$ & $\begin{array}{r}37.3 \\
\pm 0.1\end{array}$ & $\frac{36.9}{ \pm 0.1}$ & $\frac{37.07}{ \pm 0.1}$ & $\begin{array}{r}36.8 \\
\pm 0.1\end{array}$ & $\begin{array}{r}36.6 \\
\pm 0.1\end{array}$ & $\begin{array}{r}36.7 \\
-0.2\end{array}$ \\
\hline $\begin{array}{l}\text { HEART RATE } \\
\left(\text { b. } \mathrm{min}^{-1}\right)\end{array}$ & $\begin{array}{c}\bar{x} \\
\text { S.E. }\end{array}$ & $\begin{array}{r}59.9 \\
\pm 4.3\end{array}$ & $\begin{array}{r}58.3 \\
\pm \quad 3.8\end{array}$ & $\begin{array}{r}59.4 \\
\pm \quad 5.1\end{array}$ & $\begin{array}{l}163.3 \\
\pm 6.5\end{array}$ & $\begin{array}{l}162.3 \\
\pm 6.3\end{array}$ & $\begin{array}{l}155.4 \\
\pm 5.1\end{array}$ & $\begin{array}{l}168.4 \\
\pm 4.5\end{array}$ & $\begin{array}{r}162.6 \\
\pm 7.4\end{array}$ & $\begin{array}{l}159.1 \\
\pm 5.1\end{array}$ & $\begin{array}{r}81.1 \\
\pm 5.2\end{array}$ & $\begin{array}{r}77.7 \\
\pm \quad 5.8\end{array}$ & $\begin{array}{r}75.3 \\
+\quad 5.6\end{array}$ & $\begin{array}{r}67.3 \\
\pm \quad 7.0\end{array}$ & $\begin{array}{r}66.4 \\
\pm \quad 7.4\end{array}$ & $\begin{array}{r}61.1 \\
-5.1\end{array}$ \\
\hline $\begin{array}{l}\text { SYSTOLIC B.P. } \\
\text { (mnilg) }\end{array}$ & $\begin{array}{c}\bar{x} \\
\text { s.e. }\end{array}$ & $\begin{array}{r}123.3 \\
\pm \quad 1.8\end{array}$ & $\begin{array}{l}123.4 \\
\pm \quad 1.9\end{array}$ & $\begin{array}{l}125.0 \\
\pm 1.5\end{array}$ & $\begin{array}{l}188.1 \\
\pm 3.9\end{array}$ & $\begin{array}{r}177.6 \\
+-3.5\end{array}$ & $\frac{176.9^{*}}{ \pm 2.6}$ & $\begin{array}{l}193.3 \\
\pm 4.3\end{array}$ & $\frac{180.1}{ \pm 3.5}$ & $\begin{array}{l}183.3 \\
\pm 3.1\end{array}$ & $\begin{array}{l}129.7 \\
\pm 2.6\end{array}$ & $\frac{117.7^{m 77}}{ \pm 2.9}$ & $\frac{116.0^{* 7}}{ \pm 1.1}$ & $\begin{array}{l}120.3 \\
\pm 2.1\end{array}$ & $\begin{array}{l}121.1 \\
\pm 2.9\end{array}$ & $\begin{array}{r}117.9 \\
\pm \quad 1.9\end{array}$ \\
\hline $\begin{array}{l}\text { RUTE/PRESSURF } \\
\text { PRODUCT } \\
\mathrm{O}_{2} \text { UPTAKE } \\
\end{array}$ & $\begin{array}{c}\bar{x} \\
\text { s.e. }\end{array}$ & $\begin{array}{r}7.4 \\
\pm \quad 0.6\end{array}$ & $\begin{array}{r}7.2 \\
\pm 0.5\end{array}$ & $\begin{array}{r}7.4 \\
\pm 0.7\end{array}$ & $\begin{array}{r}30.7 \\
\pm \quad 1.6\end{array}$ & $\begin{array}{r}28.9 \\
\pm \quad 1.6\end{array}$ & $\frac{27.5}{ \pm 0.9}$ & $\begin{array}{r}32.6 \\
\pm \quad 1.1\end{array}$ & $\begin{array}{r}29.4 \\
\pm \quad 1.7\end{array}$ & \begin{tabular}{|l|}
29.2 \\
1.1
\end{tabular} & $\begin{array}{r}10.6 \\
\pm 0.8\end{array}$ & $\begin{array}{r}9.2 \\
\pm 0.8\end{array}$ & $\begin{array}{r}8.7 \\
\pm \quad 0.6\end{array}$ & $\begin{array}{r}8.1 \\
\pm 0.8\end{array}$ & $\begin{array}{r}8.1 \\
\pm 0.9\end{array}$ & $\begin{array}{r}7.2 \\
\pm 0.6\end{array}$ \\
\hline 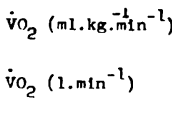 & $\begin{array}{c}\bar{x} \\
\text { S.E. } \\
\bar{x} \\
\text { S.E. }\end{array}$ & $\begin{array}{r}4.0 \\
+0.3 \\
0.29 \\
\pm 0.02\end{array}$ & $\begin{aligned} & 3.9 \\
\pm & 0.2 \\
& 0.26 \\
\pm & 0.02\end{aligned}$ & $\begin{array}{r}3.9 \\
\pm 0.2 \\
0.26 \\
\pm 0.01\end{array}$ & $\begin{array}{r}50.5 \\
\pm 1.6 \\
+3.33 \\
\pm 0.16\end{array}$ & $\begin{array}{r}48.2 \\
\pm \quad 2.2 \\
3.20 \\
\pm 0.18\end{array}$ & $\begin{array}{r}47.2 \\
\pm \quad 1.5 \\
3.07 \\
\pm 0.13\end{array}$ & $\begin{array}{r}49.2 \\
+2.8 \\
3.27 \\
\pm 0.29\end{array}$ & $\begin{array}{r}46.4 \\
\pm 2.8 \\
3.10 \\
\pm 0.25\end{array}$ & $\begin{array}{r}44.1 \\
\pm \quad 2.7 \\
2.97 \\
\pm 0.29\end{array}$ & $\begin{array}{r}4.43 \\
\pm 0.26 \\
0.34 \\
\pm 0.02\end{array}$ & $\begin{array}{r}4.30 \\
\pm 0.35 \\
0.28 \\
\pm 0.02\end{array}$ & $\begin{array}{r}4.60 \\
\pm 0.24 \\
0.30 \\
\pm 0.02\end{array}$ & $\begin{array}{r}4.37 \\
\pm 0.38 \\
0.26 \\
\pm 0.02\end{array}$ & $\begin{array}{r}3.93 \\
\pm 0.45 \\
0.27 \\
\pm 0.03\end{array}$ & $\begin{array}{r}3.86 \\
\pm 0.31 \\
0.26 \\
\pm 0.02\end{array}$ \\
\hline $\begin{array}{l}\text { RESPIRATORY } \\
\text { EXCHANGE RATIO }\end{array}$ & $\begin{array}{c}\bar{x} \\
\text { S.E. }\end{array}$ & $\begin{array}{r}0.81 \\
\pm 0.04\end{array}$ & $\begin{array}{r}0.83 \\
\pm 0.02\end{array}$ & $\begin{array}{r}0.84 \\
\pm 0.02\end{array}$ & $\begin{array}{r}0.85 \\
\pm 0.03\end{array}$ & $\begin{array}{r}0.86 \\
\pm 0.01\end{array}$ & $\begin{array}{r}0.91 \\
\pm 0.02\end{array}$ & $\begin{array}{r}0.77 \\
\pm 0.03\end{array}$ & $\begin{array}{r}0.81 \\
\pm 0.01\end{array}$ & $\begin{array}{r}0.84 \\
\pm 0.02\end{array}$ & $\begin{array}{r}0.69 \\
\pm 0.05\end{array}$ & $\begin{array}{r}0.72 \\
\pm 0.02\end{array}$ & $\begin{array}{r}0.75 \\
\pm 0.03\end{array}$ & $\pm \frac{0.64}{0.03}$ & $\begin{array}{r}0.73 \\
\pm 0.05\end{array}$ & $\begin{array}{r}0.75 \\
\pm 0.02\end{array}$ \\
\hline
\end{tabular}

Treatments - X: No Fluid W: Water Q: Experimental Drink

Levels of statistical significance: $\quad{ }^{*} p<.01 \quad * p<.05$ 
TABLE V(a): MEAN PLASMA VOLUME, OSMALALITY AND ELECTROLYTE CHANGES DURING EXERCISE DEHYDRATION

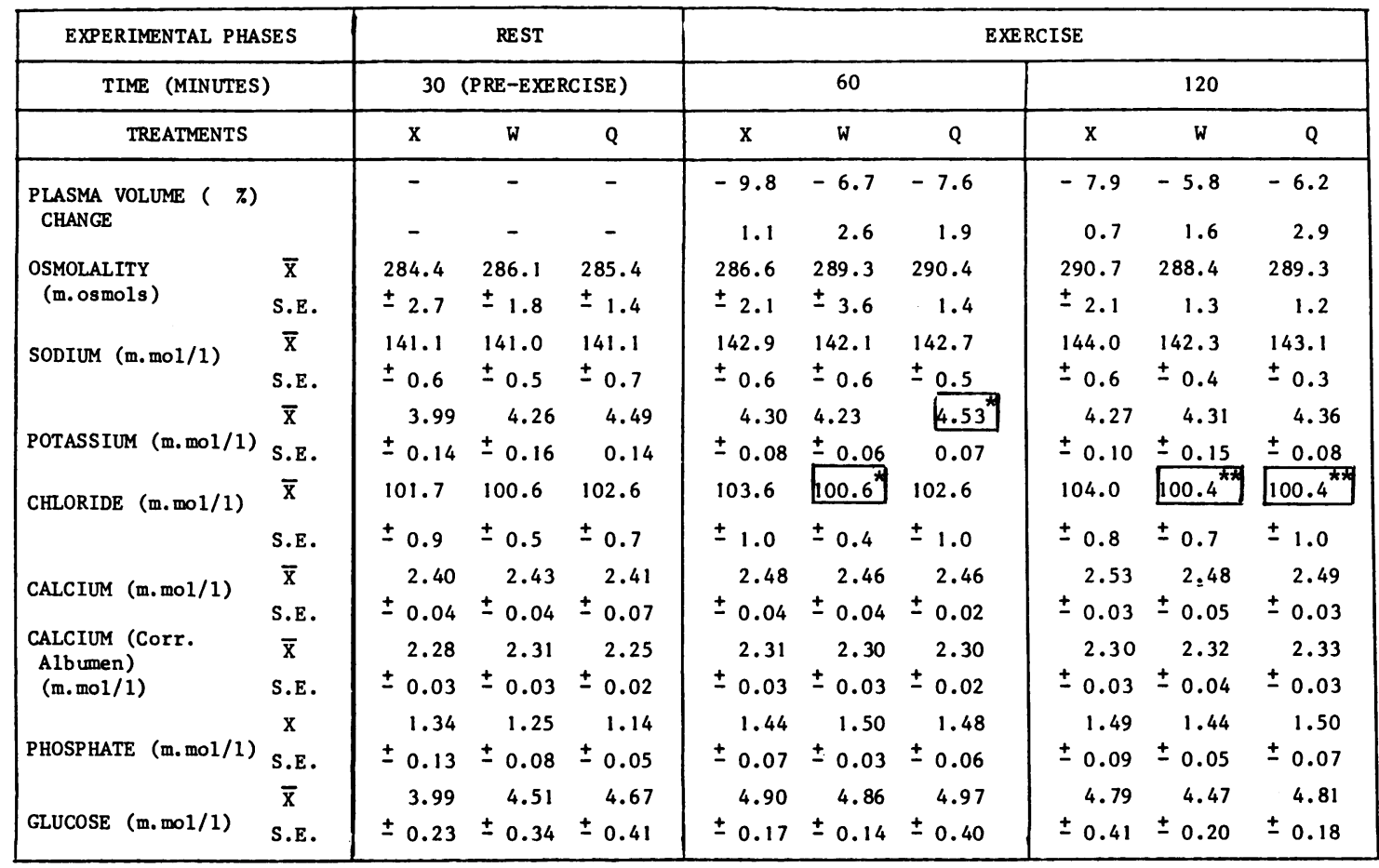

TABLE V(b): MEAN PLASMA VOLUNE, OSMOLALITY AND ELECTROLYTE CHANGES DURING RECOVERY REHYDRATION

\begin{tabular}{|c|c|c|c|c|c|c|c|c|c|c|c|c|c|}
\hline \multirow{2}{*}{\multicolumn{2}{|c|}{$\begin{array}{c}\text { EXPERIMENTAL PHASES } \\
\text { T IME (MINUTES) }\end{array}$}} & \multicolumn{12}{|c|}{ RECOVERY } \\
\hline & & \multicolumn{3}{|c|}{150} & \multicolumn{3}{|c|}{180} & \multicolumn{3}{|c|}{240} & \multicolumn{3}{|c|}{300} \\
\hline TREATMENTS & & $\mathrm{x}$ & w & Q & $\mathrm{x}$ & W & $Q$ & $\mathrm{x}$ & w & Q & $\mathrm{x}$ & W & Q \\
\hline $\begin{array}{l}\text { PLASMA VOLUME }(\boldsymbol{\eta}) \\
\text { CHANGE }\end{array}$ & & $\begin{array}{r}-3.2 \\
2.2\end{array}$ & $\begin{array}{r}-0.6 \\
1.2\end{array}$ & $\begin{array}{r}-3.3 \\
2.9\end{array}$ & $\begin{array}{r}-5.3 \\
1.9\end{array}$ & $\begin{array}{r}-0.8 \\
1.4\end{array}$ & $\begin{array}{r}-1.1 \\
3.6\end{array}$ & $\begin{array}{r}-6.1 \\
2.6\end{array}$ & $\begin{array}{r}-1.0 \\
1.6\end{array}$ & $\frac{+1.1^{*}}{3.3}$ & $\begin{array}{r}-2.0 \\
2.0\end{array}$ & $\begin{array}{r}+0.5 \\
1.7\end{array}$ & $\begin{array}{r}+1.5 \\
3.3\end{array}$ \\
\hline OSMOLALITY & $\overline{\mathrm{x}}$ & 290.6 & 286.7 & 288.9 & 291.3 & 285.0 & 287.9 & 291.1 & $284.1^{\text {** }}$ & $285.1^{*}$ & 291.3 & $283.0^{\star \star \star}$ & $286.7^{*}$ \\
\hline (m.osmols) & S.E, & \pm 3.1 & \pm 2.9 & \pm 1.2 & \pm 2.7 & \pm 2.3 & \pm 1.3 & \pm 2.0 & \pm 2.2 & \pm 1.7 & \pm 2.0 & \pm 2.1 & \pm 1.1 \\
\hline SODIUM (m. mol/1) & $\begin{array}{c}\bar{X} \\
\text { S.E. }\end{array}$ & $\begin{array}{l}145.4 \\
\pm 0.8\end{array}$ & $\frac{141.6^{* *}}{ \pm 0.7}$ & $\frac{142.6^{* \star *}}{ \pm 0.4}$ & $\begin{array}{l}144.9 \\
\pm 0.7\end{array}$ & $\frac{140.6^{* \star}}{ \pm 0.7}$ & $\frac{141.4^{* *}}{ \pm 0.5}$ & $\begin{array}{l}143.3 \\
\pm 1.1\end{array}$ & $\frac{139.9^{\star \star}}{ \pm 0.6}$ & $\frac{140.3^{\text {** }}}{ \pm 0.3}$ & $\begin{array}{r}143.4 \\
\pm \quad 1.0\end{array}$ & $\frac{140.1^{\star *}}{ \pm 0.7}$ & $\begin{array}{l}141.9 \\
\pm 0.5\end{array}$ \\
\hline POTASSIUM (m. mol/1) & $\begin{array}{l}\bar{x} \\
\text { S.E. }\end{array}$ & $\begin{array}{r}4.66 \\
\pm 0.10\end{array}$ & $\begin{array}{r}4.41 \\
\pm 0.09\end{array}$ & $\begin{array}{r}4.59 \\
\pm 0.09\end{array}$ & $\begin{array}{r}4.34 \\
\pm \quad 0.06\end{array}$ & $\begin{array}{r}4.44 \\
\pm 0.13\end{array}$ & $\begin{array}{r}4.59 \\
\pm \quad 0.15\end{array}$ & $\begin{array}{r}4.37 \\
\pm 0.13\end{array}$ & $\begin{array}{r}4.40 \\
\pm 0.14\end{array}$ & $\begin{array}{r}4.41 \\
\pm 0.18\end{array}$ & $\begin{array}{r}4.52 \\
\pm 0.14\end{array}$ & $\begin{array}{r}4.50 \\
\pm 0.08\end{array}$ & $\begin{array}{r}4.34 \\
\pm 0.14\end{array}$ \\
\hline & $\overline{\mathrm{x}}$ & 103.4 & $99.6^{\star \star *}$ & $102.3^{*}$ & 103.6 & $99.3^{* *}$ & $100.6^{\star \star}$ & 102.7 & $98.9^{* \star \lambda}$ & $100.4^{*}$ & 105.0 & $99.7^{\star \star *}$ & $101.0^{\star \star *}$ \\
\hline CHLORIDE (m.mol/1) & S.E. & \pm 0.8 & \pm 0.5 & \pm 0.7 & \pm 0.8 & \pm 0.7 & \pm 0.7 & \pm 1.0 & \pm 0.8 & \pm 0.7 & \pm 0.9 & \pm 0.6 & \pm 0.6 \\
\hline CALCIUM (m.mo1/1) & $\begin{array}{l}\overline{\mathrm{x}} \\
\text { S.E. }\end{array}$ & $\begin{array}{r}2.51 \\
\pm 0.04\end{array}$ & $\begin{aligned} & 2.41^{\star} \\
\pm & 0.03\end{aligned}$ & $\begin{array}{r}2.44 \\
\pm 0.03\end{array}$ & $\begin{array}{r}2.50 \\
\pm \quad 0.03\end{array}$ & $\pm \frac{2.41^{*}}{0.05}$ & $\begin{array}{r}2.45 \\
\pm 0.05\end{array}$ & $\begin{array}{r}2.55 \\
\pm 0.03\end{array}$ & $\begin{array}{r}2.47 \\
\pm 0.03\end{array}$ & $\pm \frac{2.40^{*}}{0.05}$ & $\begin{array}{r}2.53 \\
\pm 0.05\end{array}$ & $\begin{array}{r}2.45 \\
\pm 0.03\end{array}$ & $\begin{array}{r}2.48 \\
\pm 0.05\end{array}$ \\
\hline $\begin{array}{l}\text { CALCIUM (Corr. } \\
\text { Albumen) } \\
\text { (m. mol/1) }\end{array}$ & $\begin{array}{l}\bar{x} \\
\text { S.E. }\end{array}$ & $\begin{array}{r}2.35 \\
\pm \quad 0.03\end{array}$ & $\begin{array}{r}2.30 \\
\pm 0.03\end{array}$ & $\begin{array}{r}2.31 \\
\pm 0.03\end{array}$ & $\begin{array}{r}2.34 \\
\pm 0.03\end{array}$ & $\begin{array}{r}2.29 \\
\pm 0.05\end{array}$ & $\begin{array}{r}2.34 \\
\pm \quad 0.04\end{array}$ & $\begin{array}{r}2.39 \\
\pm 0.02\end{array}$ & $\begin{array}{r}2.34 \\
\pm 0.03\end{array}$ & $\begin{array}{r}2.31 \\
\pm 0.05\end{array}$ & $\begin{array}{r}2.38 \\
\pm \quad 0.03\end{array}$ & $\begin{array}{r}2.33 \\
\pm \quad 0.03\end{array}$ & $\begin{array}{r}2.37 \\
\pm 0.04\end{array}$ \\
\hline PHOSPHATE (m.mol/1) & $\begin{array}{l}\bar{x} \\
\text { S.E. }\end{array}$ & $\begin{array}{r}1.33 \\
+\quad 0.08\end{array}$ & $\begin{array}{r}1.36 \\
\pm 0.05\end{array}$ & $\begin{array}{r}1.41 \\
\pm \quad 0.07 \\
\end{array}$ & $\begin{array}{r}1.32 \\
\pm \quad 0.07\end{array}$ & $\begin{array}{r}1.33 \\
\pm 0.05\end{array}$ & $\begin{array}{r}1.37 \\
\pm 0.07\end{array}$ & $\begin{array}{r}1.25 \\
\pm 0.07\end{array}$ & $\begin{array}{r}1.29 \\
\pm 0.05\end{array}$ & $\begin{array}{r}1.36 \\
\pm 0.08\end{array}$ & $\begin{array}{r}1.32 \\
\pm \quad 0.06\end{array}$ & $\begin{array}{r}1.38 \\
\pm \quad 0.03\end{array}$ & $\begin{array}{r}1.45 \\
\pm \quad 0.07\end{array}$ \\
\hline GLUCOSE (m. mol/1) & $\begin{array}{l}\overline{\mathrm{x}} \\
\text { S.E. }\end{array}$ & $\begin{array}{r}4.31 \\
+\quad 0.29\end{array}$ & $\begin{array}{r}4.13 \\
\pm 0.12\end{array}$ & $\begin{aligned} 5.39^{\star *} \\
\pm 0.23\end{aligned}$ & $\begin{array}{r}4.34 \\
\pm \quad 0.19\end{array}$ & $\begin{array}{r}4.01 \\
\pm 0.11\end{array}$ & $\pm 0.19^{\star *}$ & $\begin{array}{r}4.46 \\
+\quad 0.31\end{array}$ & $\begin{array}{r}4.34 \\
+\quad 0.17\end{array}$ & $\pm \frac{6.57^{\star \star}}{0.37}$ & $\begin{array}{r}4.77 \\
+\quad 0.32\end{array}$ & $\begin{array}{r}4.19 \\
+\quad 0.09\end{array}$ & $\begin{array}{r}4.40 \\
\pm 0.22\end{array}$ \\
\hline Treatments - $\mathrm{X}$ : & Fluid & W: & ter & Experime & ntal Dr & & Levels & f statis & stical si & gnificance & & .01 & ${ }^{*} \mathrm{p}<.05$ \\
\hline
\end{tabular}


hydrate loading capability as demonstrated by the ability to significantly raise plasma glucose levels during the recovery phase. However, with the exception of plasma glucose responses, there were no statistically significant differences between the fluid treatments $W$ and $\mathbf{Q}$ in terms of plasma volume, plasma osmolality and plasma electrolyte responses during exercise and recovery.

\section{DISCUSSION}

Field Trial

The results observed from data collected during the field trial study indicated that, even during relatively moderate environmental conditions, medium distance road race cycling produced significant body weight (fluid) loss, which has been shown to be associated with physiological intolerance to work demands (Claremont et al, 1976). The implications of this finding become most important since most of the road race cyclists involved in the study were found to be relatively unaware of the importance of fluid intake practices, during training and racing, in terms of minimising cardiorespiratory and thermo-regulatory disturbances associated with prolonged, moderate to high intensity activity. Since feeding practices in road race cycling have traditionally concentrated upon the intake of solids, primarily high carbohydrate foodstuffs, in order to overcome the low point of working capability known as the "bonk", it was concluded that feeding protocols need to be reviewed in terms of the importance of fluid administration in the prevention of relative states of dehydration and heat distress.

\section{Dehydration/Rehydration Trials}

The physiological demand of exercise associated with the dehydration trial $(X)$ was significantly greater than that of the anti-dehydration trials (W and $Q$ ) in terms of the level of absolute cardiovascular, respiratory and body temperature responses to the standardised work task, therefore, trial $X$ was representative of the field trial condition. The dehydration trial produced relative physiological intolerance to the work demand, whilst the rehydration trials minimised this effect during exercise (Claremont et al, 1976; Costill et al, 1970), with a more rapid return to pre-exercise states during the immediate recovery period. However, whilst there were no statistically significant differences between the $W$ and $\mathbf{Q}$ fluid treatments, nevertheless, there was a tendency for the most consistent beneficial effect to be associated with treatment $Q$.
Similarly, the changes in plasma variable responses favoured the $W$ and $Q$ fluid treatments in comparison with the no fluid treatment condition, which characteristically resulted in changes in plasma volume, plasma osmolality and electrolyte disturbances reported in other studies (Costill et al, 1974; Costill and Fink, 1974; Costill et al, 1976). Likewise, the magnitude of changes in plasma volume and plasma osmolality during exercise associated with fluid treatments were similar to those reported in other work (Costill and Sparks, 1973) along with the trend towards the restoration of these parameters during the recovery period (Costill and Sparks, 1973). Furthermore, plasma electrolyte (sodium, chloride and calcium) increases, during exercise observed in the dehydration trials, were minimised during fluid treatments $W$ and $Q$, in accordance with other findings (Costill et al, 1970) with a return of these parameters closer to resting values observed during the recovery period. However, the physiological significance to these electrolyte changes during exercise should be considered as secondary importance to the fluid losses incurred (Costill, 1979).

It was concluded that, with the exception of the obvious carbohydrate loading capability of treatment $Q$ at the dilution used in the rehydration trial, there were only marginal benefits to be gained over using water in terms of the maintenance of plasma volume, plasma osmolality and plasma electrolyte balance close to homeostatic levels. However, this finding must be weighed against the replacement of relatively large fluid volumes to offset pre-determined weight loss estimates, in terms of the purely subjective difficulty of the provision of an "acceptable" form of fluid. Thus, consideration of the palatability and gastric acceptance qualities of the respective fluid treatments must be considered in the selection of an appropriate fluid medium.

\section{ACKNOWLEDGEMENTS}

The investigation was supported by a grant from Beecham Products Limited, Research and Development Division, and technical support was received from the Clinical Biochemistry Laboratory of Hope Hospital, Salford. Additional assistance was provided by $\mathrm{Mr}$. $\mathrm{H}$. Nelson (Coaching), and Mr. J. Mulhall and Dr. M. Al-Dawalibi (Human Performance Laboratory, Salford University). Finally, the authors would like to thank the cyclists involved who underwent such a prolonged and exhausting series of trials.

\section{REFERENCES}

Claremont, A. D., Costill, D. L., Fink, W. and Van Handel, P., 1976 "Heat tolerance following diuretic induced dehydration". Med.Sci.Sports 8 (4): 239-243. 
Costill, D. L., Kammer, W. F. and Fisher, M. A., 1970 “Fluid ingestion during distance running". Arch.Environ.Health 21: 520 .

Costill, D. L. and Sparks, K. E., 1973 "Rapid fluid replacement following thermal dehydration". Journ.Appl.Physiol. 34 (3): 299-303.

Costill, D. L., Branam, L., Eddy, D. and Fink, W., 1974 "Alterations in red cell volume following exercise and dehydration". Journ. Appl.Physiol. 37 (6): 912-916.

Costill, D. L. and Fink, W. J., 1974 "Plasma volume changes following exercise and thermal dehydration". Journ.Appl. Physiol. $37(4): 521-525$.

Costill, D. L. and Saltin, B., 1974 "Factors limiting gastric emptying during rest and exercise". Journ.Appl.Physiol. 37: 679-683.

Costill, D. L., Cote, R. and Fink, W., 1976 “Muscle, water and electrolytes following varied levels of dehydration in man". Journ. Appl.Physiol. 40 (1): 6-11.

Costill, D. L. and Burke, E. J., 1979 "Fluids for athletic performance". In: Toward an understanding of human performance. Mouvement Publications, Ithaca, New York, pp. 63-67.

Dill, D. B. and Costill, D. L., 1974 "Calculation of percentage changes in volumes of red blood cells and plasma in dehydration". Journ. Appl.Physiol. 37: 247-248.

Firth, M. S., 1981 “A sports specific training and testing device for racing cyclists". Ergonomics 24: 565-571.

Foster, C., Costill, D. L. and Fink, W. J., 1980 "Gastric emptying characteristics of glucose and glucose polymer solutions". Res.Quart.Ex.Sport 31: 299-305.

Pilardeau, P., Vaysse, J., Garnier, M., Joublin, M. and Valeri, L., 1979 "Secretion of eccrine sweat glands during exercise". Brit.Journ.Sports Med. 13: 118-121.

White, J. A., Quinn, G., Al-Dawalibi, M. and Mulhall, J., 1982 'Seasonal changes in cyclists' performance, Part I: The British Olympic road race squad". Brit.Journ.Sports Med. 16: 4-12. 